\title{
Chlorogenic Acid
}

National Cancer Institute

\section{Source}

National Cancer Institute. Chlorogenic Acid. NCI Thesaurus. Code C116073.

A polyphenol and the ester of caffeic acid and quinic acid that is found in coffee and black tea, with potential antioxidant and chemopreventive activities. Chlorogenic acid scavenges free radicals, which inhibits DNA damage and may protect against the induction of carcinogenesis. In addition, this agent may upregulate the expression of genes involved in the activation of the immune system and enhances activation and proliferation of cytotoxic T-lymphocytes, macrophages, and natural killer cells.

Chlorogenic acid also inhibits the activity of matrix metalloproteinases. 